\title{
Analysis of Factors Affecting the Website Quality Based on Webqual Approach (Study Case: XYZ University)
}

\author{
Darmawan Napitupulu ${ }^{\# *}$, \\ \#Indonesian Institute of Sciences, Puspiptek Serpong, South Tangerang, 15314, Banten, Indonesia \\ E-mail: darwan.na70@gmail.com \\ *Computer Science Department-Borobudur University, East Jakarta, 13430, DKI Jakarta, Indonesia \\ E-mail: darwan.na70@gmail.com
}

\begin{abstract}
Website is Information and Communication Technology (ICT) media, which is used to display content of information in a fast, scalable, affordable and certainly varied way. Furthermore, a website for an institution is the reflection or face of the institution in cyberspace. Therefore, improving the quality of website should be one of the main concerns to be done continuously. WebQual has been used widely to measure the quality of the website. The aim of this research is to determine the effect of WebQual independent variables namely usability, quality of information and service interaction quality toward users' satisfaction associated with the quality of the website. The method used in this research was survey method with a quantitative approach, namely multiple linear regression. Sampling was done by purposive sampling in XYZ University by distributing questionnaires to 216 respondents who are students as users of the website. The results showed that the variables of usability and services interaction have the significant and positive effect on users' satisfaction. However, the variable of information quality has no significant effect on users' satisfaction. Although the website is mandatory, information quality needs to be improved so that it can create users' satisfaction. The coefficient of determination showed by $\mathbf{5 7 . 5 \%}$ contribution of three independent variables can explain variations in users' satisfaction. This means that there are $\mathbf{4 2 . 5 \%}$ more variables or factors outside of this research model including psychological factors.
\end{abstract}

Keywords - usability; information quality; service interaction quality; users' satisfaction; multiple regression

\section{INTRODUCTION}

A website is Information and Communication Technology (ICT) media, which is used to display information content in a fast, scalable, cheap and certainly varied way. Furthermore, a website for an institution is the reflection or face of the institution in cyberspace. The role of a website has become an important part of an organization and can provide competitive advantages for organizations such as could provide services to users or customers via online. For example, many companies have been using media websites to offer products/services to their customers. With a website, companies can reach a wider market or even global market so as providing opportunities for companies to attract new customers or partners. But for non-profit organizations such as government agencies, it provides services such as a provision of information to public or licensing management via online [1] so it could improve the quality of public services. As for universities, a website is used to improve the quality of learning and their services such as online elearning technologies for the society of academicians [2]. Various benefits and advantages of website described above indicate that the improvement of website quality should be one of the main concerns to be done continuously. Improvement can be made in advance through measurement on performance or quality of a website.

A framework used to measure the quality or performance of website has been developed by several researchers such as Zeithaml and Parasuraman [3], [4] who conducted a study on the quality of Internet-based services and develop E-S-QUAL scale consisting of seven dimensions. Yoo \& Donthu [5] developed a model called the SITE-QUAL to measure perceived quality, especially on online shopping sites. Wolfinbarger and Gilly [6] developed a model of quality measurement of online services, i.e., eTAILQ which consists of 4 dimensions. In addition, Barnes \& Vidgin [7] formulated a WebQual model, which has been used extensively, which can be used to measure the quality of a website based on user perception that consists of 3 (three) dimensions, namely usability, information quality and service interaction quality [7]. WebQual model is the development of Servqual method that was widely used previously on measuring service quality where research 
instrument on WebQual was developed by Quality Function Development (QFD) method.

Various studies have used WebQual model to measure website quality in organizations such as Candra [8] who has evaluated the website quality in local government, especially in Ogan Ilir Regency with WebQual 4.0 method. The results of Candra's study [8] showed that the entire measurement of WebQual's variables namely usability, information quality, and service interaction quality has a significant effect on the value of website's measurement quality. Of these three variables, the most dominant variable on website quality is the usability aspect. In addition, Sanjaya [1] also measures the service quality in the Ministry of Communications website with the WebQual approach. In Sanjaya's research [1], it showed that one of the dimensional measurements of WebQual namely information quality has no significant effect on user satisfaction [1]. While Syaifullah \& Dicky [9] also measure the website quality of a with the WebQual method on a company that has a portal of news information service provider. From the results of multiple linear regression analysis performed, it is obtained that three variables of WebQual 4.0 are also positive and have a significant effect on the quality of company's website [9].

In the earlier study conducted, measuring website quality has been done at XYZ University with the WebQual method based on the users' perspective [2]. In that study, it is known to what extent of the gap between perception and expectations of users to the condition of website services provided by the organization, in addition to the priority of website improvement in the future. This study is a continuation of the previous one [2] which will be further examined the correlation between each dimension or variable of WebQual and website quality. Furthermore, we want to determine whether variables of usability, information quality, and service interaction quality have a significant effect on website quality. In other words, this study aims to find out how significant the effect of each WebQual measurement variable on the assessment of website quality at XYZ University. This research is significant relative to previous work [1], [8], [9] because it makes a contribution to test Webqual model whether it can be applied to the domain of higher education especially $\mathrm{XYZ}$ University. Besides, this research also helps the campus to know factors that influence the website quality based on user perspective.

\section{MATERIALS AND METHODS}

As mentioned earlier, the website plays an important role in providing information or services that can be reached easily and quickly by users. Measurement of website quality is needed to determine the extent of which users' satisfaction level and to gain feedbacks. The framework used in this study is WebQual 4.0 that has been widely used for measuring service quality in the previous works. WebQual 4.0 has three-dimensional measurement namely usability, information quality, and service interaction quality, thus in this study, we only focused on these three dimensions or factors.

The research method used in this research is a survey with quantitative approach. An instrument in the form of the questionnaire was prepared based only on the WebQual model used as the conceptual framework of measurement in this study. WebQual has three-dimensional measurement namely usability, information quality, and service interaction quality. Usability is a quality associated with the design of the site, for example, appearance, ease of use, navigation, and images presented to users [7]. In other words, usability dimensions describe how users feel the interaction with the website. The list of dimensions and variables that describe WebQual 4.0 model [7] shown in Table 1 will be used in developing the questionnaire of the study.

\section{A. Usability}

Usability dimension based on WebQual 4.0 consists of 8 (eight) items or measurement indicators namely ease of operation, interaction with website is clear and understandable, ease of navigation, ease of finding the address of website, attractive display, appropriate in arrangement the layout information, display which according to the type of websites as well as the expansion of knowledge of information [7].

TABLE I

DIMENSIONS AND VARIABLES OF WEBQUAL 4.0

\begin{tabular}{|c|c|}
\hline Dimensions & WebQual Variables \\
\hline Usability & $\begin{array}{l}\text { 1. Ease of operation } \\
\text { 2.Interaction with website is clear and } \\
\text { understandable } \\
\text { 3. Ease of navigation } \\
\text { 4. Attractive display } \\
\text { 5. Display is suitable for type of website } \\
\text { 6. There is additional knowledge of website } \\
\text { information } \\
\text { 7. Appropriate in arranging layout information } \\
\text { 8. Ease of finding the website address }\end{array}$ \\
\hline $\begin{array}{l}\text { Information } \\
\text { Quality }\end{array}$ & $\begin{array}{l}\text { 9. Providing reliable information } \\
\text { 10. Providing update information } \\
\text { 11.Providing easy for reading and } \\
\text { understandable information } \\
\text { 12. Providing detailed information } \\
\text { 13. Providing relevant information } \\
\text { 14. Providing accurate information } \\
\text { 15.Presenting information in appropriate format }\end{array}$ \\
\hline $\begin{array}{l}\text { Service } \\
\text { Interaction } \\
\text { Quality }\end{array}$ & $\begin{array}{l}\text { 16. Has good reputation } \\
\text { 17. Providing security to complete transaction } \\
\text { 18. Sense of security in delivering personal data } \\
\text { 19. The existence of community atmosphere } \\
\text { 20. Ease of interest and important to remember } \\
\text { 21. Ease to communicate } \\
\text { 22. The high level of confidence of } \\
\text { goods/services delivery }\end{array}$ \\
\hline $\begin{array}{l}\text { Overall } \\
\text { Impression }\end{array}$ & 23. Site quality is good overall \\
\hline
\end{tabular}

\section{B. Information Quality}

Information quality is a quality of the content contained on a website, the suitability of the information for purposes such as format and coherence [7]. In other words, the quality of the information is the quality of website information which becomes users' needs, which has the characteristics such as accurate, timely and relevant. Information quality dimension based on WebQual 4.0 has 7 (seven) items or measurement indicators namely providing clear information, providing reliable information, providing up to date 
information, providing relevant information, provide easy to read and understandable information, providing detailed information and providing information in an appropriate format [7].

\section{Service Interaction Quality}

Service interaction quality is the quality of service interaction experienced by users when they investigate deeper into the website, which manifested as confidence and empathy, for example, the issue of transactions and information security, product delivery, personalization and communication with site owners [7]. Service interaction quality based on WebQual 4.0 includes seven (7) items or measurement indicators namely have good reputation, get security to complete a transaction, a sense of security in delivering personal data, ease to attract interest and attention, the sense of community, easiness to give feedback as well as the high level of trust on information on website.

Based on Table 1 above, it can be seen that there are three (3) independent variables in the WebQual model as measured by the 22 questions. In addition, there is 1 (one) dependent variable namely users' satisfaction measured by one question in the form of assessment of overall site quality. Users' perception of website or quality information system is a system where users are satisfied with website quality [10], [11]. These qualities can be explained by 3 (three) dimensions or variables of WebQual 4.0. Some researchers suggest WebQual variables can be used to predict users' satisfaction and users' interests to use the website again [7], [12], [13], [14].

The primary data collection is done to a number of respondents who are part of the population where the population in this study are all students of XYZ University. The number of samples is 216 respondents selected by purposive sampling with criteria of respondents have used the website of XYZ University. The questionnaire was designed using a Likert scale to assess users' perception of website quality consists of four answer choices of "1" = Strongly Disagree, "2" = Disagree, "3" = Agree and "4" = Strongly Agree. This is intended to avoid the tendency of respondents to be neutral. Based on the WebQual 4.0 model [7] and following previous research [1], [8], [9], [10], then research hypotheses are constructed where there are three hypotheses which are shown in Fig. 1 below:

H1: Usability has a positive and significant effect on users' satisfaction

$\mathrm{H} 2$ : Information quality has a positive and significant effect on user satisfaction

H3: Service interaction quality has a positive and significant effect on user satisfaction.

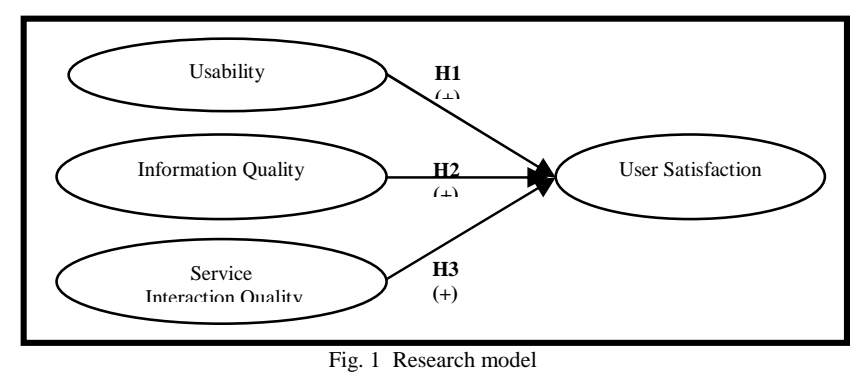

To test the hypotheses in this study, multiple regression analysis is performed based on the functional relationship or causality of two or more independent variables with one dependent variable. The independent variables, in this case, are usability, information quality, and service interaction quality while the dependent variable in this study is users' satisfaction.

\section{RESULTS AND DISCUSSION}

\section{A. Validity and Reliability Instrument}

In this study, the sample of 216 respondents chosen by purposive sampling was undergraduate students that still active academically in odd semester 2016/2017. Total respondents were from four Departments namely Computer Science, Economic, Law, and Engineering Departement based on criteria that the respondents have been using the website of XYZ University for minimum one year. Therefore, the students at least would be in $3^{\text {rd }}$ semester or above. The process of data collecting was conducted from September to November 2016 with detailed demographics presented in Table 2 below. In terms of gender, the respondents were 123 female $(57 \%)$ and 93 male $(43 \%)$. In terms of the semester, $35.8 \%$ (77) of the sample were in $3^{\text {rd }}$ semester, $44.5 \%(96)$ of the sample were in $5^{\text {th }}$ semester, and only $19.7 \%$ (43) of the sample were in 7 th semester. In terms of web usage frequency, $12.6 \%$ of the sample had less than once a month, $26.3 \%$ of the sample had once a month web usage, $34.7 \%$ of sample accessed the website once a week and $26.4 \%$ of the sample had every day of web usage. Based on the results of data collection to 216 respondents, there were only 204 questionnaires data that could be used for subsequent analysis then response rate obtained $94.4 \%$. Those 204 questionnaires data were completed by respondents and no missing data of them.

TABLE II

DEMOGRAPHIC OF RESPONDENTS

\begin{tabular}{|l|c|c|c|}
\hline \multirow{3}{*}{ Gender } & Item & Frequency & Percent \\
\cline { 2 - 4 } & Male & 93 & $43 \%$ \\
\hline \multirow{4}{*}{ Semester } & Female & 123 & $57 \%$ \\
\hline \multirow{3}{*}{$\begin{array}{l}\text { Web Usage } \\
\text { Frequency }\end{array}$} & $5^{\text {th }}$ semester & 77 & $35.8 \%$ \\
\cline { 2 - 4 } & $7^{\text {th }}$ semester & 96 & $44.5 \%$ \\
\cline { 2 - 4 } & $\begin{array}{c}\text { Less than } \\
\text { once a month }\end{array}$ & 28 & $19.7 \%$ \\
\cline { 2 - 4 } & Once a month & 56 & $12.6 \%$ \\
\cline { 2 - 4 } & Once a week & 75 & $26.3 \%$ \\
\cline { 2 - 4 } & Everyday & 57 & $26.7 \%$ \\
\hline
\end{tabular}

In previous research related to the analysis of university's website quality using WebQual approach [2], validity and reliability tests of research instrument had been done. These tests were done to determine the extent of the accuracy and consistency of instruments or measuring tools used. Validity and reliability of an instrument are essential to ensure the feasibility of research instruments [15]. Valid instrument indicates that it can measure what is desired while a reliable instrument showed the consistency of measurement which, if carried out several times, will generate the same data.

In this study, the coefficient or validity index of the instrument in this study can be seen from the value of $r$ in 
the corrected item-total correlation column where if $r_{\text {count }}$ is positive and greater than $r_{\text {table }}$, then the item is valid [16]. The value of $r_{\text {count }}$ in corrected item-total correlation column is more thorough than the coefficient value of Pearson product-moment correlation. In relation to the correlation number that item of variables is said to be valid if it has a coefficient of at least 0.3 [16]. Conditions of validity are the minimum requirement, as expressed by Cronbach Alpha coefficient [17]. When the correlation number of calculation results is greater than the critical number, the question item is valid and significant. Conversely, if the correlation number of calculation result is smaller than the critical number of correlation tables, the question item is deemed not significant and should be aborted or corrected [17].

A valid instrument is generally reliable, but reliability testing must be done because instrument reliability indicates the extent to which the instrument is reliable or unreliable [18]. To assess the reliability of internal consistency among question or statement items in an instrument on the research techniques, Cronbach's alpha (alpha coefficient) can be used. Alpha coefficient varies from 0 to 1 where a measurement item said to be reliable if it has a value of alpha coefficients greater than 0.6 [17]. According to Churchill and Goodhue, Cronbach's alpha is commonly used in measuring reliability [12].

Questionnaire validity testing conducted on 22 items of WebQual, this was because there was one (1) item which was outside the domain of education namely concerning the delivery of goods and services. The item fits better with the commerce domain, so it was not included in the questionnaire. Results of questionnaire validity testing showed that all items in the instrument were declared as valid because it has met the minimum requirements that $r_{\text {count }}$ (corrected item-total correlation) value $>0.3\left(\mathrm{r}_{\text {table }}\right)$ with a significance level of $5 \%$ as shown in Table 3.

TABLE III

VALIDITY TESTING

\begin{tabular}{|c|c|c|}
\hline Variable & $\begin{array}{c}\text { Corrected Item- } \\
\text { Total Correlation }\end{array}$ & Result \\
\hline USA_1 & 0.725 & VALID \\
\hline USA_2 & 0.821 & VALID \\
\hline USA_3 & 0.642 & VALID \\
\hline USA_4 & 0.327 & VALID \\
\hline USA_5 & 0.481 & VALID \\
\hline USA_6 & 0.383 & VALID \\
\hline USA_7 & 0.383 & VALID \\
\hline USA_8 & 0.383 & VALID \\
\hline IQA_1 & 0.708 & VALID \\
\hline IQA_2 & 0.761 & VALID \\
\hline IQA_3 & 0.895 & VALID \\
\hline IQA_4 & 0.895 & VALID \\
\hline IQA_5 & 0.843 & VALID \\
\hline IQA_6 & 0.843 & VALID \\
\hline IQA_7 & 0.843 & VALID \\
\hline SIQ_1 & 0.608 & VALID \\
\hline SIQ_2 & 0.510 & VALID \\
\hline SIQ_3 & 0.879 & VALID \\
\hline SIQ_4 & 0.879 & VALID \\
\hline SIQ_5 & 0.879 & VALID \\
\hline SIQ_6 & 0.879 & VALID \\
\hline OVI_1 & 0.752 & VALID \\
\hline
\end{tabular}

Questionnaire reliability testing performed on each dimension of WebQual measurement namely usability, information quality, service interaction quality and users' satisfaction based on Cronbach's Alpha score as shown in Table 4 below. Cronbach's alpha is a technique that would indicate internal consistency index is accurate, fast, and economical. The instrument is said to meet the Cronbach alpha reliability if the value is greater than 0.60 .

TABLE IV

RELIABILITY TESTING

\begin{tabular}{|l|c|c|}
\hline \multicolumn{1}{|c|}{ Dimension } & Cronbach's Alpha & Result \\
\hline Usability & 0.857 & RELIABLE \\
\hline Information Quality & 0.746 & RELIABLE \\
\hline $\begin{array}{l}\text { Service Interaction } \\
\text { Quality }\end{array}$ & 0.671 & RELIABLE \\
\hline Overall Impression & 0.693 & RELIABLE \\
\hline
\end{tabular}

Based on Table 4, results of questionnaire reliability testing showed that all dimension of WebQual has been reliable because it has already met the minimum requirements for Cronbach's alpha > 0.6 [2]. The usability dimension has 0.857 of Cronbach's Alpha value; information quality has score 0.746 of Cronbach's Alpha, service interaction quality has 0.671 and users' satisfaction measured by overall impression showed satisfaction of reliability result $>0.6$. Based on validity and reliability testing conducted before, it could be said that both dependent and independent variables were eligible to do further analysis especially hypothesis analysis or testing.

\section{B. Hypothesis Testing}

In this section, research hypotheses will be testing by using quantitative approach through multiple linear regression analysis. In this study, there are three hypotheses to be tested, namely, whether usability has a positive and significant effect on users' satisfaction, whether information quality has a positive and significant effect on users' satisfaction and whether service interaction quality has a positive and significant impact on users' satisfaction. To test these hypotheses in this study, individual parameter test (t-test), simulation parameter test ( $\mathrm{F}$ test) and determination coefficient test $\left(\mathrm{R}^{2}\right)$ were conducted.

F test also called as model feasibility test is an initial stage of regression model identification estimated in this study. What means by reliable is decent estimated model used to explain the influence of independent variables on the dependent variable. $F$ test is also often called as the variable simultaneous test to know whether all the independent variables influence the dependent variable simultaneously. Conclusion drawing on a simultaneous test (F test), i.e when the probability value of $F_{\text {count }}$ is smaller than the error rate of 0.05 then it can be said that the estimated regression model is reliable or all independent variables simultaneously influence the dependent variable. Conversely, if the probability value of $\mathrm{F}_{\text {count }}$ is greater than the error rate of 0.05 , then it can be said that the estimated regression model is not reliable or no simultaneous effect between independent variables and dependent variable. F test results in this study can be seen in Table 5 as follows: 
TABLE V

Results Of Variable Simultaneous Test (Test F) ANOVA

\begin{tabular}{|l|r|r|r|r|l|}
\hline \multicolumn{1}{|c|}{ Model } & Sum of Squares & df & $\begin{array}{c}\text { Mean } \\
\text { Square }\end{array}$ & F & Sig. \\
\hline $\begin{array}{l}\text { Regressio } \\
\mathrm{n}\end{array}$ & 108.399 & 3 & 36.133 & $\begin{array}{r}110.98 \\
9\end{array}$ & $.000^{\mathrm{b}}$ \\
\hline Residual & 65.111 & 200 & .326 & & \\
\hline Total & 173.510 & 203 & & & \\
\hline
\end{tabular}

a. Dependent Variable: User_Satisfaction

b. Predictors: (Constant), Qual_Inter, Usability, Qual_Info

Based on ANOVA result on Table 5 above, it can be seen that the value of $F_{\text {count }}$ by 110.989 with a probability of $F_{\text {count }}$ by 0.000 . This shows that the probability of $F_{\text {count }}$ obtained was much smaller than $0.05(5 \%)$, it can be said that the estimated regression model is reliable to use in this study. In other words, all of the WebQual variables namely usability, information quality, service interaction quality have a significant influence on users' satisfaction simultaneously.

T-test in multiple linear regression is intended to test the estimated parameters (regression coefficients and constants) to estimate equation/multiple linear regression models is a proper parameter. The term proper here means that the parameter is able to explain the behavior of independent variables in affecting the dependent variable. The t-test is also called as individual parameter test, means that t-test can be used to know whether independent variable individually affects the dependent variable. In the research, there are three (3) independent variables namely usability, information quality and service interaction quality which are thought to affect the dependent variable, i.e., users' satisfaction. It is stated in the three hypotheses $(\mathrm{H} 1, \mathrm{H} 2$, and H3) were tested as mentioned in the previous section. Conclusion-drawing in individual parameter test ( $\mathrm{t}$ test) is also seen from the value $t_{\text {count }}$ probability wherein if the value of $\mathrm{t}_{\text {count }}$ probability is smaller than the error rate of 0.05 then it can be said that independent variables have significant effect on dependent variable, whereas if the value of the probability $t_{\text {count }}$ is smaller than error rate of 0.05 it can be said that the independent variables have no significant effect on the dependent variable.

The results of hypothesis testing through T-test could be seen in Table 6 as follows:

TABLE VI

RESULTS OF INDIVIDUAL PARAMETERS TEST

\begin{tabular}{|l|r|r|c|c|c|}
\hline & \multicolumn{2}{|c|}{$\begin{array}{c}\text { Unstandardized } \\
\text { Coefficients }\end{array}$} & $\begin{array}{c}\text { Standardized } \\
\text { Coefficients }\end{array}$ & & \\
\cline { 2 - 4 } \multicolumn{1}{c|}{ Model } & \multicolumn{1}{c|}{$\mathrm{B}$} & \multicolumn{1}{c|}{$\begin{array}{c}\text { Std. } \\
\text { Error }\end{array}$} & Beta & \multicolumn{1}{c|}{$\mathrm{t}$} & Sig. \\
\hline (Constant) & -.406 & .310 & & -1.309 & .192 \\
Usability & .726 & .172 & .476 & 4.217 & .000 \\
Qual_Info & -.373 & .197 & -.216 & -1.890 & .060 \\
Qual_Inter & .738 & .151 & .536 & 4.881 & .000 \\
\hline
\end{tabular}

a. Dependent Variable: User_Satisfaction

Based on Table 6 above, multiple linear regression equation was obtained as follows:

$$
Y=-0.406+0.726 X 1+-0.373 X 2+0.738 X 3
$$

The above equation can be explained as follows:

- Constant value of -0.406 indicates that if the usability, information quality, and service interaction quality are equal to zero, then the value of users' satisfaction will decrease by 0.406 units

- Usability had a regression coefficient with a positive direction for 0.726 that if the value of usability increase by 1 unit, then the value of users' satisfaction will be increased by 0.726 units.

- Information quality had a regression coefficient of 0.373 with a negative direction that if the value of information quality incremented by 1 unit, then the value of users' satisfaction will decrease by 0.373 units.

- Service interaction quality had a regression coefficient with a positive direction for 0.738 that if the value of usability increase by 1 unit, then the value of users' satisfaction will be increased by 0.738 units.

Based on Table 6 above, the results of the test of individual parameters (t-test) also indicate the probability of significance for the variables of usability by 0.000 (less than 0.05 ) and the value of $t_{\text {count }}$ by 4.217 (greater than $t_{\text {table }}$ ) with a regression coefficient of 0.726 (positive). It means that the first hypothesis (H1) is acceptable namely usability has a significant and positive effect on users' satisfaction because it has met the requirements. The implication is that XYZ university websites deemed useful for users, in this case, are the students. This is because university website is mandatory where students must use the website to support the teaching and learning process starting from the academic registration as Study Plan Card to enroll courses, e-learning activities to receive Study Result Card. Thus, the university's website is considered useful or beneficial to users, especially to help students' academic activities, which is said that it has given users satisfaction. This finding is similar to other previous studies [1], [7], [8], [9], [10] that showed independent variable of usability significantly influence on users' satisfaction.

Variable of information quality has a probability of significance by 0.060 (greater than 0.05), and the value of $\mathrm{t}_{\text {count }}$ was -1.890 (less than $\mathrm{t}_{\text {table }}$ ) with a regression coefficient of -0.373 (negative). This means that the second hypothesis (H2) is not acceptable namely information quality has no significant positive effect on users' satisfaction. The implication is that information quality contained on the website is deemed not meet users' expectations because the university website is mandatory then it is still used by students as users. This finding is in line with other research [1] where information quality variable is not considered influential on the website users' satisfaction because of mandatory reasoning. However, this research finding will be valuable information for management to improve the information quality (content) on the website such as up-todate information, detailed information, relevant information, etc. Thus, it can meet the users' expectations or satisfaction of the website.

For the variable of service interaction quality, it has a probability of significance by 0.000 (less than 0.05 ), and the value of $\mathrm{t}_{\text {count }}$ was 4.881 (greater than $\mathrm{t}_{\text {table }}$ ) with a regression 
coefficient of 0.738 (positive). This means that the third hypothesis (H3) is acceptable namely service interaction quality has a significant and positive effect on users' satisfaction. The implication is service interaction quality on websites deemed sufficient by users. The website already provides ease of communications; it is reliable since it is supported transactions security so causing a sense of security in the transaction such as Study Planning Card, e-learning, etc. Thus the website already provides highly qualified service interaction based on the experiences of respondents using the website. The result of the study also supported previous studies [1], [7], [8], [9], [10] that empirically demonstrated the variable of service interaction quality significantly influence on users satisfaction.

The coefficient of determination test $\left(\mathrm{R}^{2}\right)$ describes effect variations of independent variables on the dependent variable. In other words, the coefficient of determination shows the proportion of the effect of all independent variables on the dependent variable. The coefficient of determination is measured using Adjusted R Square because in this study the number of independent variables more than one. The results of coefficient of determination test $\left(R^{2}\right)$ can be seen in Table 7 as follows:

TABLE VII

RESUlTS OF COEFFICIENT OF DETERMINATION TEST

\begin{tabular}{|c|c|c|c|c|}
\hline Model & $\mathrm{R}$ & $\mathrm{R}$ Square & $\begin{array}{c}\text { Adjusted R } \\
\text { Square }\end{array}$ & $\begin{array}{c}\text { Std. Error of the } \\
\text { Estimate }\end{array}$ \\
\hline 1 & $.785^{\mathrm{a}}$ & .617 & .575 & .26961 \\
\hline
\end{tabular}

Based on Table 7, the results of coefficient of determination test can be seen that the value of Adjusted R Square is 0.575 . It means that $57.5 \%$ of the variation of users' satisfaction can be explained by the factors of usability, information quality, and service interaction quality. While the rest of $42.5 \%$ is explained by other factors not included in the linear regression model outside technological factor, that is a non-technological factor such as psychological factors or social influence [19], [20]. This study as said only focus on technological factors that influence the quality of website based on customer's perspective including usability factor, information quality factor, and service interaction quality factor. The framework WebQual used could explain only $42.5 \%$ of users' satisfaction variation. The result finding is also in line with other research argue that technology adoption should account for social influence as psychological factors. TAM (Technology Acceptance Model) as a well-known model for measuring user acceptance of information system was also argued because it only emphasized in technological aspect and ignoring social influence [21]. The inclusion of social influence was indeed the motivation for updating TAM which had provided a more detailed account of the key forces of the underlying judgments of perceived usefulness, "explaining up to $60 \%$ of the variance in this important driver of usage intentions" [19].

The Unified Theory of Acceptance and Use of Technology (UTAUT) by Venkatesh et al. [20] is a further development which combines some major theories (e.g. TAM, Theory of Planned Behavior, and Innovation Diffusion Theory) from the IS literature. The model has three direct determinants of intention to use (performance expectancy, effort expectancy, and social influence) and two direct determinants of use behavior (intention and facilitating conditions). There the intention and facilitating conditions are mediated by experience, voluntariness, gender, and age. Venkatesh et al. [20] suggest that given that UTAUT explains as much as 70 percent of the variance in intention, it is possible that we may be approaching the practical limits of our ability to explain individual acceptance and usage decisions in organizations.

\section{CONCLUSIONS}

Based on the research that has been done, it can be concluded:

- The first hypothesis (H1) is acceptable from the analysis where the variable of usability has a significant and positive effect on users' satisfaction. It can be shown from the results of the t-test with a significant probability of 0.000 with a regression coefficient which is equal to 0.726 .

- The second hypothesis (H2) is not acceptable from the analysis where the variable of information quality has no significant and negative effect on users' satisfaction. It can be shown from the results of the ttest with significance probability of 0.060 with a regression coefficient which is equal to -0373 .

- The third hypothesis (H3) is acceptable from the analysis where the variable of service interaction quality has a significant and positive effect on users' satisfaction. It can be shown from the results of the ttest with a significant probability of 0.000 with a regression coefficient which is equal to 0.738 .

- Based on the coefficient of determination test results which show of $57.5 \%$ contribution of the three independent variables to explain the dependent variable namely the users' satisfaction. Thus, there are other $42.5 \%$ variables which have the effect out of the model. Therefore, the suggestion given is more research activity needed to find variables or other factors outside the model that also affect users' satisfaction including psychological or social influence factors.

- Based on ANOVA result showed the probability of $\mathrm{F}_{\text {count }}$ obtained was much smaller than $0.05(5 \%)$, it can be said that the estimated regression model is reliable to use in this study. It also means that all of the WebQual variables namely usability, information quality, service interaction quality have a significant influence on users' satisfaction simultaneously.

- Based on the results of the analysis which indicate that the university XYZ website is mandatory for users, in this case, the students to support a variety of teaching and learning processes ranging from academic registration until study results card that can only be accessed via the web. Thus, it is inevitably for students to use the website for their studies. But through the study, it is known that the information quality does not affect users' satisfaction. This study suggested that the design of information systems need to be improved so that it can provide qualified information for its users. 


\section{ACKNOWLEDGMENT}

We would like to thank the board of the university that has supported the research activities was being carried out properly.

\section{REFERENCES}

[1] I. Sanjaya, "Pengukuran Kualitas Layanan Website Kementerian Kominfo Dengan Menggunakan Metode Webqual 4.0," Jurnal Iptekkom Vol. 14, No.1, pp: 1-13, 2012.

[2] D. Napitupulu. "Evaluasi Kualitas Website Universitas XYZ Dengan Pendekatan Webqual," Buletin Pos \& Telekomunikasi, Vol. 14, No. 1, pp: 51-64, 2016.

[3] Parasuraman, V.A. Zeithaml, and A. Malhotra, "E-S-QUAL: A multiple-item scale for assessing electronic service quality," Journal of Service Research, Vol. 7, No. 3, pp. 213-234, 2005.

[4] E. Cristoal, C. Flavian, and M. Guinaliu, "Perceived e-service quality: Measurement validity and effects on consumer satisfaction and website loyalty," Managing Service Quality, Vol. 17 No. 3, pp. 317340, 2007.

[5] B. Yoo, and N. Donthu, "Developing a scale to measure perceived quality of an Internet shopping site (SITEQUAL)," Quarterly Journal of Electronic Commerce, Vol. 2 No. 1, pp. 31-46. Breckling, Ed., The Analysis of Directional Time Series: Applications to Wind Speed and Direction, ser. Lecture Notes in Statistics. Berlin, Germany: Springer, 1989, Vol. 61, 2001.

[6] M.F. Wolfinbarger, and Gilly, "ETAILQ: Dimensionalizing, measuring and predicting e-tailing quality," Journal of Retailing, Vol.79 No.3, pp. 183-198, 2003.

[7] S.J Barnes and R.T. Vidgin, R.T, "Assessing The Quality of Auction Web Sites," Proceedings of the Hawaii International Conference on System Sciences, pp. 1-10, 2002.

[8] M. Nilashi, D. Jannach, and O.B. Ibrahim, "Recommendation Quality, Transparency, and Website Quality for Trust-Building in Recommendation Agents," Electronic Commerce Research and Applications, Vol. 19, pp. 70-84, 2016.

[9] S. Kanaujiya, P. Gusain, N. Agarwal, and S. Wadhwa, "Analysis of Web Quality Provided by Pintwire Informatics in IT Industry: Using
WebQual Instrument," Global Journal of Enterprise Information System, Vol. 7, No. 1, 2015.

[10] N. Elangovan, "Evaluating Perceived Quality of B-School Websites," Journal of Business and Management, Vol. 12, No. 1, pp: 92-102, 2013.

[11] R.J. Jain and S. Rangnekar, "Measuring Website Quality of The Indian Railways," International Journal of Entrepreneurial Knowledge, Vol. 3, No. 1, pp: 57-64, 2015.

[12] E. Loiacono, "WebQual: A Web quality instrument," AMCIS 1999 Proceedings, pp. 1002-1004, 1999.

[13] E.T. Loiacono, R.T. Watson, and D.L Goodhue, "WEBQUAL: Measure of website quality," 2002 Marketing Educators Conference: Marketing Theory and Applications, Vol. 13, pp. 432-437, 2002.

[14] F. Davis, "Perceived Usefulness, Perceived Ease of Use, and User Acceptance of Information Technology," MIS Quarterly, Vol. 13, No. 3, pp: 319-339, 1989.

[15] D. Napitupulu, D.I. Sensuse, and A. Murni, "Testing the Validity of Maturity Model for E-Government Implementation in Indonesia," International Journal of Social, Behavioral, Educational, Economic, Business and Industrial Engineering, Vol. 9, No. 2, 2015.

[16] D.H. Lee, S.Y. Park, and J.S Ha, "Patient Satisfaction with OutPatient Rehabilitation Therapy: Validity and Reliability," The Journal of Physical Therapy Science, Vol. 28, pp. 3354-3356, 2016.

[17] H.B. Santoso, I. Nurrohmah, S. Fadhilah, W.H. Goodridge, "Evaluating and Resedigning the Self-Monitoring Tool," International Journal on Advanced Science, Engineering and Information Technology, Vol. 7, No. 1, 2017.

[18] A.A. Patak, H.A. Naim, A. Maruf, and M.N Abdul, "Design and Validation of Online Learning Environment Questionnaire," International Journal on Advanced Science, Engineering and Information Technology, Vol. 6, No. 3, 2016.

[19] F.D. Davis, "Perceived Usefulness, Perceived Ease of Use, and User Acceptance of Information Technology," MIS Quarterly, Vol 13, No. 3, pp.319-339, 1989.

[20] M.D. Williams, N.P. Rana, and Y.K. Dwivedi, "The Unified Theory of Acceptance and Use of Technology (UTAUT): a Literature Review," Journal of Enterprise Information Management, Vol. 28 , No. 3, 2015. 